\title{
マツタケの生活 微生物社会の一員として—
}

\author{
小川 真 \\ 京都大学農学部応用植物学研究室
}

「現代は，一方では実験室的な研究とともに，他方で は山を使った種々の実験を計画的におし進めるべき時代 であって，この両者が相まったとき，今後 10 年間のマ ッタケ学の進歩には見るべきものがあるはずである。そ して，これは輸入や模倣でない日本独特の成果である」 と, 1964 年刊行の “マッタケー研究之增産一” に浜田 博土がその“苦悩”を披瀝したが，その後の研究はます ます拡大の一途をたどっている。1964 年以前のわれわ れの知識や考光は上記の本に述べられて和り，文献もほ 柇その中に収録されているので，ここでは是の後のこと について，われわれの得た知識をつづってみようと思う。

「別に，私は話すこともないんだが……」とマッタケ がのり出してきた. “われわれの得た知識”といらのは間 違っている。あなた方がうろらろ私のまわりをらろつい ているのがあまりかわいそらだから，少しでも助けてあ げようと思って私が問わず語りに話したことを，あなた は並べたてようとしているだけじゃないか。私はカビの 王者だと自負していますよ．人間が多少私のことを知っ たと自惚机ても，そりゃあ上っ面にしか過ぎませんよ。 それが証拠に，人間はまだ私を思いのままにすることが

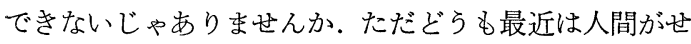
っかちになって, 試験管にとじこめて振り回したり，マ ッの根を切り刻んだり，むりやり若いマッにくっつけた り，括まけに山の“シロ”まで掘りか光すので不安には なりますがね。そう簡単に王座はゆるぎませんよ。まし て城を明け渡すなんてね。亦あ，私のきのこをもっと沢 山食べたいと思うのなら，まず人間が今まで軽視しがち だった分野を開いて知識を身につけて出直さなければ無 理でしょう。微生物が test tube から出て, 自然の中へ 戻ることがまず先決です. さらに微生物生理学, 生態学, ことに土壤微生物学, 菌根学, 微生物分類学, 形態学,
樹木生理学, 森林生態学, 中でも根の生理·生態学, 土壌 学, 等々枚挙に暇ない流ど学問と称する分野が開かれな ければなりません，ところが，近年私は人間の無知上欲 張りにいささかあきれているんですよ，私を知るために 必要な知識も身につけないで, 沢山でて海しいとか, 何 とか作れないものかとか，山を放り出しておいて，年と ったアカマツにつけとか, むりな注文を次々と出してく るのでね. 何も私は，人間のためにきのこを作ってるん

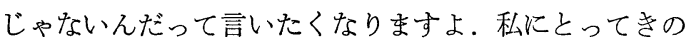
こは他の場所に新しい“シロ”をつくる種になる大事な胞 子を作るための生殖器官でしてね。亦文ってみ机ば高 等植物でいら花とよく似たものなんです. 3 年ばかり前 に言ったことですけど，私を知りたいのなら，土の中で ぞんな暮し方をしているのかよく見て，根本的浡考方 を改めてもらわなければ城を明け渡したくても, 明け渡 せないじゃないかって㸚」と言われて，われわれの考克 方もかなり大きく変化し始めている，これから述べるこ とは事実に反する推測を含んでいるかもしれないが，誤 りは，われわれがマッタケの話を聞き違えたためである と思っていただきたい。

\section{1.きのこの生活—“シロ”}

秋, 温度が低下し, 降雨が続くとアカマツ林に輪をえ がいて，きのこ，いわゆるマッタケが発生する、これは マッタケ菌の花であって，その下にある栄養体である菌 糸もマッの根についてやはり環状に広がっている。この 菌系の環は上表の落葉, 落枝や腐植層を取り除いてみる と，白い菌系帯が明瞭に区別されるのでそれとわかる。 この菌系の層はアカマッの若い根と一緒に主として有機 質の少ない母土猿（ $\mathrm{A}_{1} \sim \mathrm{B}$ 層）飞繁茂している.

マッタケが輪になって子実体を発生するのはカビの習 
性としてみれば当然のことである. カビは総じて水面に 波紋が広がるようにプレート上でも広がってゆく。しか し，自然界で完全な円になる例はそれほど多くはない。 いわゆる fairy ringを作るきのこは, 担子菌の中でよ く知られている。 ムラサキシメジ, Clavaria, Agaricus, Marasmius, Boletus に属する数種のもの, ドクササュ, アンズタケなどがある、特そらく、下等な菌類にもこれ らのものに似た生活型をとるものが多いであろう。カビ には個体といら単位があてはまらない、常に個々の部分 が独立する可能性を持った細胞の集団である. 担子菌を

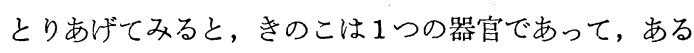
程度の組織化と分化が進んで拉り，まとまりをもってい る.したがって，たとえばきのこのひだ だけを切りと って成熟させようとしても，Coprinus などの場合の例 外はあるとしても，栄養源がなければそのまま死んでし まらか, 栄養源があれば脱分化が起こるか, それも不可 能となるかのいずれかである。

一方, 栄養体である菌采体またはコロニーのまとまり はきわめてルーズなもので，一部を切っても全体が変化 することは汪とんどなく，条件が整っていればそのまま さらに栄養生長を続ける。栄養体である菌系は, 生殖器 官を作らせないで栄養生長を続けさせると，液体に浸漬 培養した場合のように周囲が注ぼ均一な条件であれば， すべての方向に放射状に生長し，コロニーは球形になる はずである．寒天のプレートに植えた場合には，下部に 深く入った半球形もしくは円盤状になり, 当然, 上半分 に伸長するべき菌系は平面に沿って伸びるか，aerial hyphae を形成する.さらに不均一な土壌その他の固形 のものに植えた場合は複雑な形に変化してゆく．もっ之 も,こうしたコロニーの形状は枝分かれの仕方や代謝産 物の影響などによって，その種独特の形になって桩大す る. そこで, 上面が気体で下が土壌といった条件にあっ て，菌が土壌に棲息したとすると，そこで円盤状に広が るためには，まず3つの条件が整っていなければならな い媒体となるもの（支持物体一この場合土壌の物理的 性質）が均一であること, すなわち, 媒体が均一な物理 的性質を持ち，それが菌に対して常に，ある許容範围内 で均一な条件を整えていること，次いで，えさとなりう るもの(培養のための栄養源)の分布, たと觉ば根とか, 落葉, 落枝之か, 腐植の分布が一様であること, もしく はそれら培養基が常に更新されること、第 3 に敵となっ て拮抗する他の生物がいないこと，もしくは協同して働 くことによってより強い生物を駆逐することが可能とな る保護者なたは協力者がいること，などに起因すると考
えられる、マッタケについていらならば, 完全な輪状発 生が認められるのは, マッの根, すなわち党さが均一に 分布している林, 土壤がかなり均一である所, 他の微生 物が比較的少ない所などの条件が整っている場所である。 マッタケの場合, えさとなるマッの根を分岐伸長させて, ひきずってゆくことができるので，えさについては均一 さを作り出してゆく，また他の微生物をある程度除外す る能力も持っているので，敵を少なくすることもできる. 菌根菌の中で, マッタケのようにえさを自分の進む方向 にひきずってゆく能力のないものや，木材腐朽菌のよ5 に枯木に定着するものや, 年々更新してゆく落葉につく 落葉分解菌艺の他についても, 学さの要求度や質や量, 物理的環境, 敵となるものなどは種々様々ではあろらが, 理想的な状態では自然界においても円盤状に広がって良 いはずである。ところが実際には, 必ずしもえさの分布 は均一ではない場合が多く，まして自分の進む方向に党 さをつれてゆける能力を持ったものは少ない．物理的条 件も, 競争相手の分布も一様ではなく, 競争相手はまた, それぞれその固有の要求を充たすために努力している.

菌類の自然界に打ける生活型をさめている最も重要な 条件は, えさの条件であろう. 他養性生物である以上, えさの分布に適応することは避けられないし，またそれ が種固有の型となって遺伝的に固定し，条件を良くして もその適応性を示すものが多い。たとえば，ナラタケの ように根状菌系束を作ってえさからえさへと渡り歩くも のがあり, 純粋培養をしても根状菌系束ができ上がる. ナラタケ以外にも Marasmius の多くのものにこのよう な例が見られる。またより不完全な菌糸束を作って生長 するもの，木材腐朽菌などにもこれに似た性質を示すも のが少しある、たと究ばヒラタケ、シイタケなど.

菌根菌は純粋培湌が困難であり，培湌基上では菌糸束 を作らず，コロニーを作るが（テングタケの類, チチタ ケの 2,3 のものなど), 自然界では菌系束を作ってかな りの距離を移動し, host となる植物の侧根のごく若い 発根部位に近づくと，まつわりついて mantle を作り， えさをとる。ただしこの菌系束は根以外のもの，たとえ ば腐植の中などにこまかく枝分かれしていることもある。

腹菌類の中にも, 根状菌糸束もしくは菌糸束を作って 広がるものが多く, 担子菌の生活型の中では上記のよう な菌糸束を作って生活する型が最も多いといわれている. さらに落葉, 落枝や, 枯木, 腐植などのかなり長期にわ たって安定したえさ（分解が遅く持続的にえさがとれる もの）につくものの中には, 定着して, えさがなくなる まで子実体を出しつづけるものもある。 
われわれは，菌類全般にわたって，こうした生活の単 位を“シャ”と呼んでいる，生態学的には，あるカビが 生活する場所と，そこにあって影響を与えたり受けたり するものすべてを含めた社会をシロという．シロといら 热は古くからマッタケの出る場所を示す意味として使わ れていたものである。

きのこが輪状発生をするのは格別不思議なことではな い.マッタケやその他のものが輪状に発生するのは, い や地のせいであるが，根本的には上に長々と述べたコ口 ニーの型と生活型の問題である.この点については後に ふれることとする。

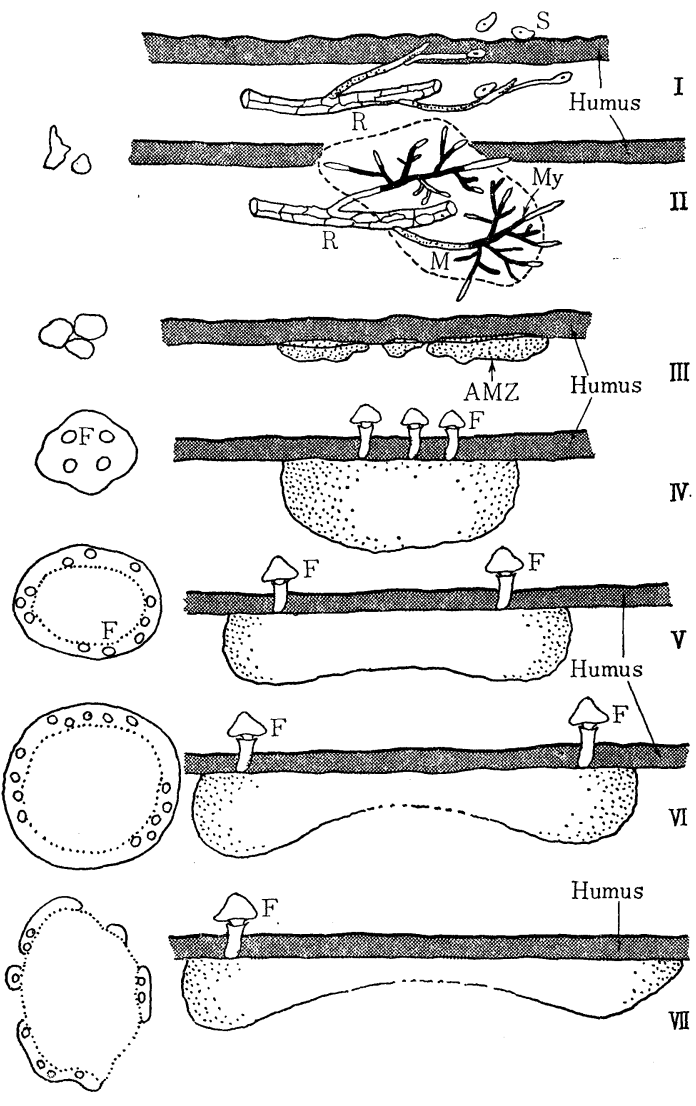

図 1 マツタケのシロの形成から消失まで

$\mathrm{R}:$ 根, $\mathrm{M}:$ 菌系, $\mathrm{My}:$ 菌根, $\mathrm{F}:$ 子実体, $\mathrm{AMZ}:$ 活性菌根带

I：若い根に胞子から発芽した菌系がつく.

II : 菌根の形成.

III : 菌根が集まってシロを作り始める.

IV : シロの発生, 子実体がで長める.

$\mathrm{V}, \mathrm{VI}:$ :シロの拡大.

VII：シロの崩壞が始まる.

右はマツタケのシロの断面図，左は上から見 たマツタケのシロ.

\section{2. “シロ”の齢}

マツタケのシロの発達について概念図を作ると図1の ようになる.アカマッの樹齢が 20〜30 年ぐらいになる と, マッタケが発生し始める。菌根が形成される, いわ ばアカマツがマツタケに感染するのは,この 2,3 年前 と推定されるが，感染初期については今のところわから ない，初め子実体は円盤状に広がった菌糸体から，群が って発生し，数年を経て次第に完全な円に近くなる. 30 年から 40 年ぐらいの樹齢の林で最盛となり，70〜80 年 になると衰退する。老龄林ではシロがきれぎれとなって， 次第に消える，このようにマッタケのシロ自身の龄はア カマツの樹齢の中にはめこまれている．これもえさとな る若い根の分布やその生長量に主因があると考光られる が，一部には林の齡に従らマッタケ以外の微生物フロー ラの変化が関与しているかもしれない.

マッタケの場合, アカマッにつくという点だけを強調 することができない. アカマッの根について生活するこ とは,すでにその林の一部であり, 後にふれるように, 多くの影響を林全体に与え，林に侵入することによって 環境の一部になり，アカマッとマッタケといった関係は， 1+1=2 にはならなくなる。杂た,この両者だけでは説 明のつかない問題が数多く現われてくる. 生物学の環境 論という難解な問題がここでも現われる.

\section{3. “シロ”の構造}

地下に埋もれた栄養体を見るためには, 溝を掘って断 面を見なければならない，中心を通る直線に沿ってシロ を掘ると図2のようになっている，土壤中には白い菌糸 のかたまりが見党，その中にマッの細根が多量に伸長し ている．白い菌采はマツタケだけとは限らないが，やや 束状になって広がり, 深さは浅い所で $10 \mathrm{~cm}$, 深い所に なると $30 \mathrm{~cm}$ 以上にも達する。この菌系の量の多い所汪 どマツタケも大きいものが出る. 根の生長部位は菌系と 根が土を抱きこんでやや硬くなった塊状の菌系層の先端 部に集まり，外側に向かって伸びている。また，種々の 方向から伸びた根も, この層で分肢し黒化して菌根を作 っている. 根の量は菌系層の未侵入部では少なく，菌系 が進むにつれて刺激され若い根が生長し, 菌根層で急激 に根の量が増加する. 根はシロの内側から外側に向かっ て伸長分岐したものが大半である. 図2 のIの部分,す

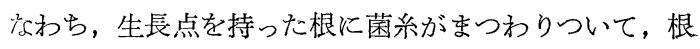
が黒化し，菌根としての働きが最も活発に行なわれて いると考学られる部分を, 活性菌根帯 (active mycor 


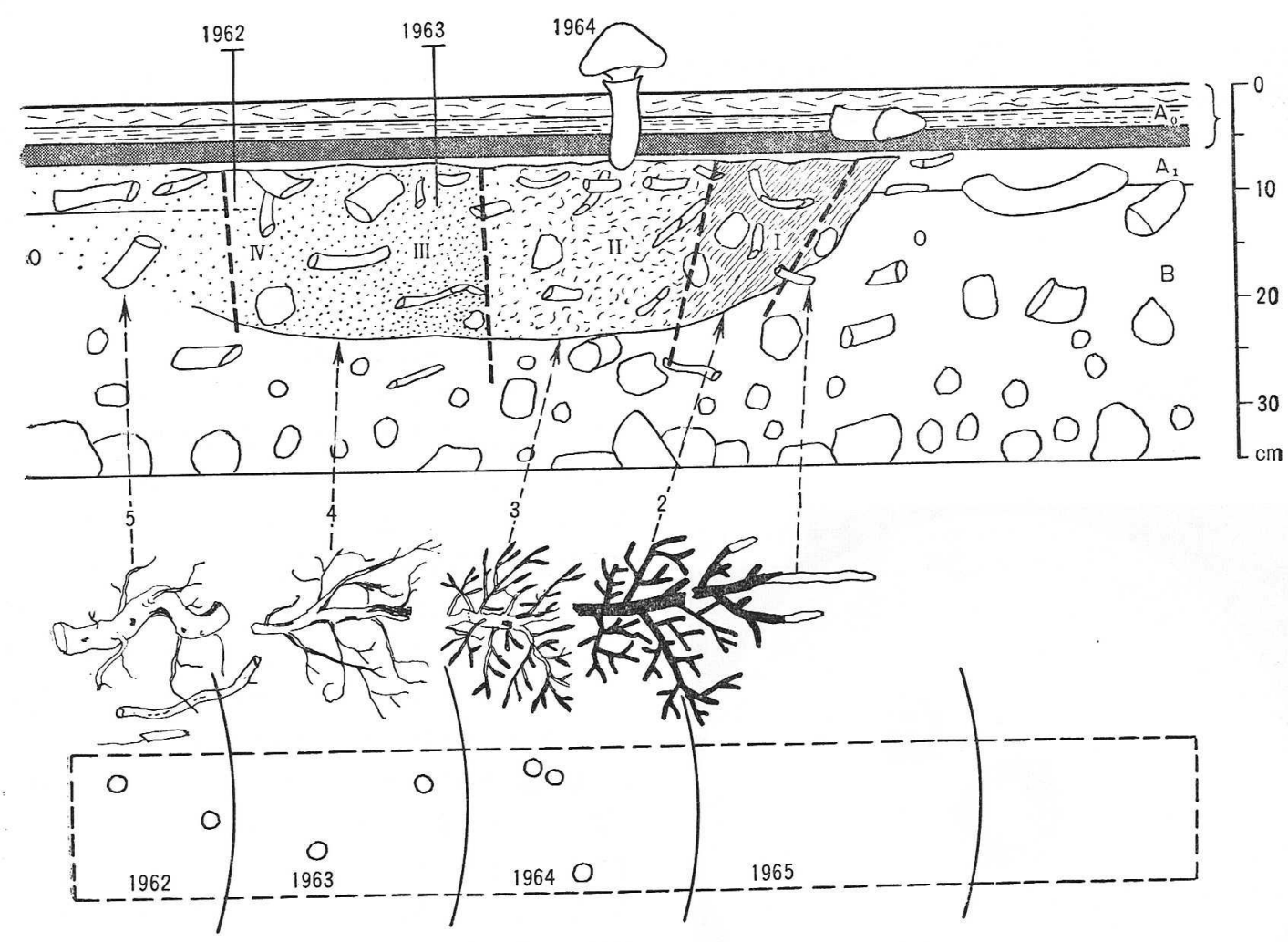

図 21965 年 5 月におけるマツタケのシロの土壤断面図

$0 \sim \mathbb{N}:$ 土壇の状態. $1 \sim 5:$ 菌根の段階.

下の破線部は試清の位置，○印はマッタケの発生位㨁，下の同心円は 1 年間炕菌根層の抎大する範围 を示す (小川・浜田, 1965).

rhizal zone； AMZ) と称している. マッタヶ菌が通り すぎ, 子実体の出た後では, いったん菌根として役目を 果たした根は後続する他の菌類によって分解されたり， 生長が止まって枯死したりして消えてゆくので, シロの 中心近くでは細根の量は次第に少なくなり, 新しく生長 する根もなくなる。主根の生長点は菌に侵されることが ないので, 勢力が落ちない間は外に向かって伸び, シロ の外側にあって発根する根は次々と菌を受けとって先に 伸ばす、したがって，シロの前方にある根は補充の役割 をしている。.土壌はシロの外側では湿っており，一般に 瞕色で, 菌糸が進さにつ机て乾燥し, 不透水層が形成さ れる. 子実体が発生すると, 含水量 $10 \%$ 前後となり (Sagara, 未発表), 土壌構造にも顕著な変化が連続的に 現われてくる (Murata, 未発表). $\mathrm{pH}$, 酸化還元電位な ぞも变化する (Sagara, 未発表)．降雨や乾燥の激しい ときなどに、シロは内部の水を一定に保とうとする緩衝 作用を示すといわれる。

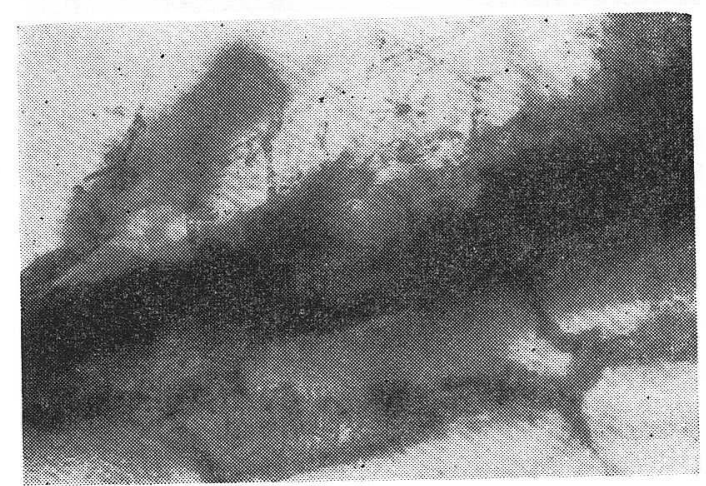

図 3 菌根の切片

上部の菌系は，おそらくマッタケ菌系であろう．表皮の細胞 はこわれ，皮層の外部の細胞間隐に菌系が入っている，細胞膜 は暗褐色に变色している.

\section{4. “シロ”一微生物の社会}

菌系層, 菌根層として示した部分は, マッタケとアカ マッの根だけから成り立っているのではない，シロには 


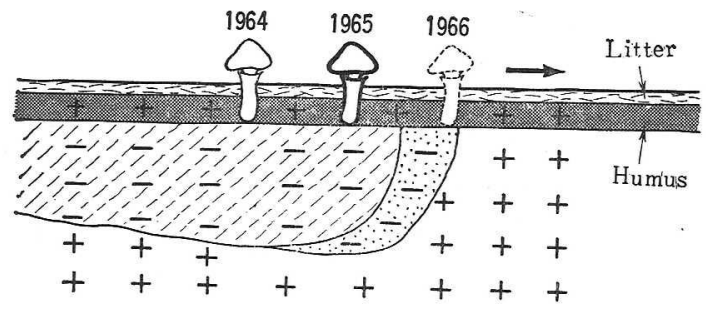

図 4 マツタケのシロの細菌, 放線菌排除層 (小原原図から)

$\therefore$ は活性菌根带.

+ : 紐菌, 放線菌が分離される.

一：細䔉，放線菌が分毞されない。

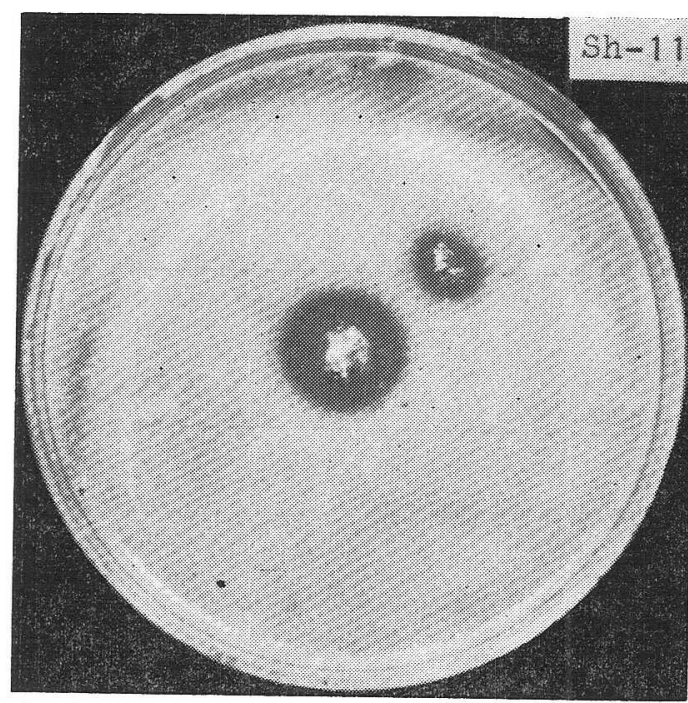

図 5 活性菌根による細菌の生長阻止効果

マッタケのシロの外から分離された土堙細菌 (Sh-11) を供 試した. 中央の白色の 2 点は菌根を含んだ土壤塊. 周辺の白色 部は細菌の生長した所. 菌根周辺の黑色部 (透明带) は細菌の 生長が阻止された所.

[H. Ohara: Proc.Jap. Acad., 42, 503 (1966)]

常に Mortierella sp. (nana-type) が，どこでも多量に 随伴している。これは $\mathrm{AMZ}$ からもマッタケの石突きか らも分離される．カビのうちンロではこれだけが残り， 他の土壤菌として知られているもの, Trichoderma 類, Penicilium 類, Aspergillus 類, Fusarium 類, Absidia 類などは分離されない(Ogawa. 未発表)。もっともマッ の根からはマッタヶ以外のものが菌根の老化段階に応じ て種及分離される。マッタケは生長を始好たばかりの若 い根について栄養を吸收する、菌系は表皮上皮層の細胞 間隐に入り (図 3)，根に 2 次生長が起こって樹皮ができ ると皮尿とともに脱離する。側根では 2 次生長が起こら
ず，生長点まで菌が入って黒化したまま枯死する，菌根 層の最も顕著な特徴は多くの菌類を排除するばかりでな く，細菌，放線菌を排除することである(図 4).これ は $\mathrm{AMZ}$ からとった菌根によって最も強く現われる（図 5). 菌がついて黑化した根は，抗生物質様のものを分 泌して細菌，放線菌を排除し，いったん排除されると外 側のフローラと同じ状態に復するのには相当の年月を要 すると考兄られる。この排除効果は 1 次的には物質で起 こり，2次的には乾燥や不透水層の形成，カビの占有， 根の老化物の集積といったことによって長期間続くもの と思われる。これがマッタケのいわゆる“いや地”であ る.しかし，いや地が何によって起こるかという問題は 複雑である、単一の原因ではなく，おそらく，上に述べ てきた種々の原因の総合的な結果であるらし，マッタヶ が年々外側にのみ広がって輪になることも，このいや地 が大きく働いているためである。なお，この排除作用は マッタヶの菌系, マッの根個々では起こらず, 自然状態 のマッとマッタケによる菌根で初めて見られる作用であ る (Ohara, 1966)。また，ここにいら排除現象子菌根か ら由来する物質単一では起こらない，とくに菌類に対す る場合は，えさとなる物質のとり合い，空間の占拋も大 きく働いているであろう．菌根層の先端部では，マッの 根以外のものをえさとする菌類が多少混入していること がある.ある1つの組織を持って平衡状態にある微生物 集団に生活型を異にする他の生物が侵入するときには， かなり強い力で平衡状態を破る必要があるだろう。この 場合，安定した社会の成員すべてを抑觉る場合と，その 中の主要な一員を抑えて平衡を破る場合とがある、マツ タケはほとんどすべての成員を抑制するため，いったん 定着さえすれば，容易に消えることがなく，消えるとき は觉さの消耗が多分に関係するものと思わ礼る。ただし， この排除作用はシ口形成の初期にはそれほど強い之は考 えられず，ある程度の量達して実際の効果を現わすと 考学られる。まして山は開放系であり，土は不均一な媒 体であり，微生物はおの沶のの生活を保って連なってい る.この作用が，ぞこまで連鎖反応を惹起しているのか， 今のところ知り得べくもない。

このような特殊な社会, シロをさらに広い場, アカマ ッ林という1つの系にはめこんだとき：シロはどのよう な意味を持つのか，ある時間に限定した見方ではなく， 時間の経過を考虑した歴史として見るとどうなるのか， 種々難解な問題が出てくる。 


\section{5. “シロ”の拡大}

上述のような菌根の集団は, 季節的変化を示しつつ, 年々外方に広がる。マッタケが発生を始めると, マッタ ケ菌系はケバ立ら, Mortierella sp. がさかんに繁殖し， 水が吸い上げられて, 土は乾燥し, 土壌は団粒化する。 菌根は全体が黒化して細くなり, 分解過程に移行してゆ くが，シロの先端に近い所では活発な菌根が残り，菌系 も変質しないまま残る。秋，根がわずかに伸長を開始す ると，それにそって菌系も伸びるが，冬の間作の生長 が止むため，これを追い越して前方に菌系だけの層を作 る.春には根がこの菌系の層を通り妨て, 菌系層の先 端に生長点を出しているのが見られる.この時期（4〜 5 月）になると，新しく生長をした根の基部から菌が侵 入を始め側根の発根を促して, 次々と若い根をらやす。 したがって, シ口の菌根の量は春から夏以かけて增加し， 夏, 主根の生長が弱まると, 側根は徒長して細根の量が ふ党, 秋までに根の生長はほぼ最大值に達する。側根の 生長点や主根の勢力の落らたものでは先端まで菌系に拉 执われ，黑化することが多い，春から秋へかけて，マッ タヶは栄養源をマッの根からとり，秋にきのこを出す準 借を完了する。排除作用もこの時期が最大となる.

\section{6. マッタケのえさ}

マッタタの笑養要求性は他の菌根菌と同様にかなり限 られている。炭素源はグルコース, フラクトース, マン ノース，マルトースなどを利用し，澱粉もビタミン類が あれば利用できる。セルロース，リグニン，シュクロー ス, ラクトース, キシロースなどは利用しない, 窒素源 としては，アンモニア態窒素，アミノ酸類を利用するが， トリプトファン, チロシン, バリンなどは窒素源にもな らず, 少量でも阻害的である, 硝酸, 亚硝酸態窒素は利 用しない、栄養生長のための最適 $\mathrm{C} / \mathrm{N}$ 比はほぼ $20: 1$ で,かなり高濃度の糖でもよく生長する。ビタミン類の 中では $\mathrm{B}_{1}$ は添淁絶刘要求に近い, 他のものにもわずか な効果は認められる。微量のアミノ酸, 種々の植物ホル モン類，核酸の塩基なぞにも促進效果がある。ミネラル としては， $\mathrm{Mg}, \mathrm{Ca}, \mathrm{Fe}, \mathrm{Mn}, \mathrm{Zn}$ などがあればよく， $\mathrm{P}$ の量は $\mathrm{KH}_{2} \mathrm{PO}_{4}$ の $1 \mathrm{~g} / l$ 程度で充分である. 一方, 菌根のエタノール抽出物やマッの根の抽出物の中にも, 生長を促進する物質があるが, 水溶性の物質であるら. マッの根は，中心柱に測粉粒を多く含んで沶り（図 6), 各季節を通じてさほどの增減がない。一般に菌が侵入す ると, 細胞内の潵粉が消失するのはよく知られている現

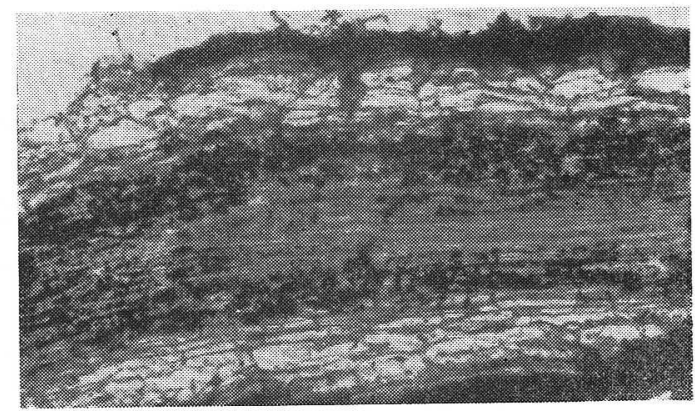

図 6 菌根内の澱粉粒の分布

澱汾粒は中心柱に黒色の粒となっている. ヨードョードカリ染色.

象である、マッタらの場合, 菌が澱粉粒を積極的に分解 利用するといらより, むしろ根が自身の生長のため使 らのを横から奪っていると考兄られる。なぜなら，菌は 表皮と皮層のごく表面に近い細胞間吵に入るだけで，中 心柱には入れないからである。また皮層の細胞膜は菌が 侵入すると変色し, 内部には老化するに従って, 樹脂様 の物質が沈着する、特とらく、われわれの知らない微妙 な変化が短時間のうらに起こるのであうう。

要求性, 生産性といった栄養や代謝隹関する問題は, 培養の困難さによっていっそうむずかしくなる. plate 上でコロニーが直径 $1 \mathrm{~cm}$ に達するのに，30〜40 日を 必要とするので, 気の短い人にはお付合いしかねるしろ ものである. 最適 $\mathrm{pH}$ は $5.0 \sim 5.5$, 最適温度は $22 \sim 25$ ${ }^{\circ} \mathrm{C}, 30^{\circ} \mathrm{C}$ になると数時間で死隇する。一方，マッタヶ の生活している場所は mineral soil といわれる有機質 の貧弱な所で，マッの根以外，汪とんど何もない所すら ある. 以上のことから，マッタケ菌とアカマッは共利共 生的な関係ではなく, むしろ, マッタケ菌が一方的に根 に喰いついているようであるが，新しい根を発根させる ことから, 根のミネラル, 窒素源などの吸収に有益であ ると言光なくもない，また栄養不良，とくに窒素不足の 所に育ったマッの糖過剩症を救っているのかもしれない。 物質の交換も含めて, これらの働きがどれほどの比重を 共生関係に占めているのかは, まったくわからない，共 利共生といらのは基準のとり方（根と菌だけ，植物全体 と菌, ある生態系と菌, または菌の栄養生長と植物, 菌 の生殖生長と植物)によって自ずから意味が異なってく る. 菌根即共利共生といらのは早計であり, 菌根が寄生 的とか共生的とかいった表現すら気休めに過ぎない。

\section{7. 子実体形成}

秋に子実体を作る準備が完了し, 栄養菌系の成熟が進 
むと，菌系は次第に束状からケバ立って aerial hyphae が多くなり，19〜 $15^{\circ} \mathrm{C}$ の温度になると，毛系玉のう な primordia がでさる。これは前年の秋生長した部分 そとの年の秋までに生長した部分の菌根層の上表一腐 植層直下一一無数に作られる。しかしこれがすべて きのこになるのではなく，何かの原因で selection が起 こり, 頂芽優勢と同じように何本かが出て, 他は消える. また数本出るとその部分に物質の流れが集中するためか， かなり群がって発生する傾向がある。も乙子実体の発生 条件が長く続けば，かなり長期にわたってバラバラと出 るはずであるが, マッタケの場合は条件の許容範国が狭 く，年に 2 度，すなわら梅雨期と 9 10 月に限られる. もっとも地方によって発生時期が異なり, 富士心のコメ ツが林の場合には，7月から〜9月まで続けて出る。原 基形成のための温度条件はその変化ではなく，ある範囲 (19〜15ㄷ)であればよい。これは実験室的にも土壤を支 持体とした試験管培養によって確かめられる（図 7). ところがこれを子実体にまで生長させることは今のとこ ろできない, 要求する栄養源を変えても, 形成時に栄盖 を補ったり，質や量を変えても，特殊なるのを添加して もだめである。そこでもら一度山に帰ってみよう。マッ

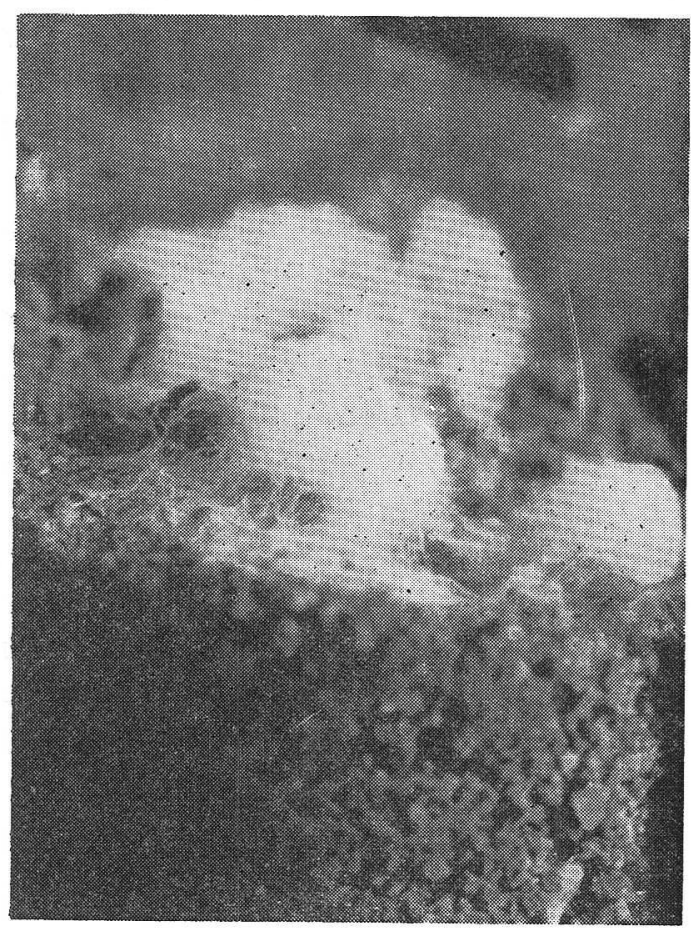

図 7 土壤培養によって試験管内に発生したマツ タケの子実体原基
タケの子実体は土から出ている，腐植から出ることはな く，腐植のまったくない所では土の下から土を割って出 る.マッシュルームに置き土が必要なことや, ンイタケ のホダ木に樹皮が必要なのと似かよっている。しかし， 上に土をかけても，ガスを変えても，しめりを与光ても 大きくならない、離れて 1 個所だけきのこが1本出た所 を掘ってみると，土がひどく乾いて変質しているので， その部分の菌糸が子実体を出すために使われたことにな るが，150 g ぐらいの子実体 1 本に菌根椾は $1 l$ 程度必 要になるらしい。これだけの菌糸を育てるには数年を要 する。また，えさはマツの細根から吸いとっているが， その根の数はきわめて多く，長さに直してみても，菌根 のシロ当りの長さは相当なものであろう。むして根は他 のものが侵入するのを機械的に物質的に抑制し，若い根 の上では医とんどマッタヶ菌系だけが荃われており，そ のえさは年間絶え間なく存在する。山の水はきれること がなく，温度や湿度，ガスなどの条件も安定している。 これを人為的に再構成すれば人工栽培も可能となるか子 しれない.

白い毛糸玉のような原基は, やや大型の容器に植えて, 低温を与党ると, コロニーの先端からやや内側に輪状に できる．これは他のきのこにも見られるが，このことは 刺激を受ける部位がある程度定まっていることを示して いる．ある器官ができるためには，そのもら一段前に別 の準供をしていなければならない。マッタケの場合，菌 糸を寒天に植えると平たく広がるだけで，温度を下げて もかたまりは生じない，ところが，土壌を使らと菌糸は aerial hyphae $と$ vegetative hyphae に分かれ, aerial hyphae が集合したよらになって原基ができる。 aerial hyphae の形成は土壤の粒度によって支配され，大き過 ぎても，粘土のように微細でもよくない，また支持体に 土譬を使っても，水の量が多過ぎたりして孔隙が少なく なると，寒天に植えた場合と同様になる。培養基の支持 体を変觉ることによって微生物の性質は顕著に変化する。 おそらく，呼吸や代謝産物も大さく変化するであるらし， 形態的に変化するのは肉眼的にも明らかである。この種 の例は他の微生物についても起こる. 液体培養や寒天培 鉒などは万能ではない.カビにとっては振湯培差も迷惑 至極な方法である。

原基ができ，きのこへと大きくなるためには，物理的 条件と, えさの与え方, えさの質と量などを整えてやる 必要があるのはもらろんであるが，マッタケのよらな菌 根菌は子実体を作る過程に必要とする栄荃源をどのよう にして得ているのだるらか。体内に貯蔵したものを一時 
に使い尽す， host であるマッから 量や質の変化したものが集中的に送 られている，もしくはその両者が同 時に起こるなどのことが考光られ る．他のきのこ類では子実体の量は 栄養体の量にかなり比例して赫り， マッタヶの場合にも同様である。さ らに，きのこを一度出すと一定期間 休息を要するものが多く，きのこを 出すために使われた菌系は消隇する ことも多い，したがって，抢そらく

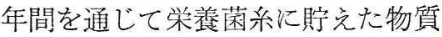
を一時に消費すると考光た洼らが妥 当であるが，ごく少量の菌系で充分 子実体を作る菌の例もあるので断定 はできない，他の菌では子実体形成 時に兄さの要求性が変わったり，ビ タミン要求，Pの要求などが大とな る例もある。したがって，マッタケ の場合にも，マッの生理の樹齢によ る変化や季節的变化を知る必要が生 じてくる。

\section{8. 予実体の分化}

子実体がその本来の役割である胞 子形成と散布を完了するまでには， 種々の生長段階を通らなければなら ない、マッタケではかたまりのます 球状に肥大し, lamella が分化する のに時間がかかる。高さが 1 2 cm になってようやく lamellaができ， 同時に軸は伸長を始め，かさが開く まで伸長し，かさが開くと伸長が止 まる。これは胞子の成熟段階に応ず る。エノキタケ，ヒトヨタケの仲間 などは内部分化が早く，かたまりが できると同時に lamella が分化して いる．こうした分化段階の遅速はき のこによってまらまちであって，一 律波うことができない。な掊嬑 条件を変えることによって，分化の 段階ある所で止めたり，とばしたりすることも可能で ある.忠たきのこ類は，この分化段階に応じて刺激感受性 が異なり、したがって運動性が異なる。ある段階ではガ
表 1 マツタケとその類縁菌の寄主と菌根の形態

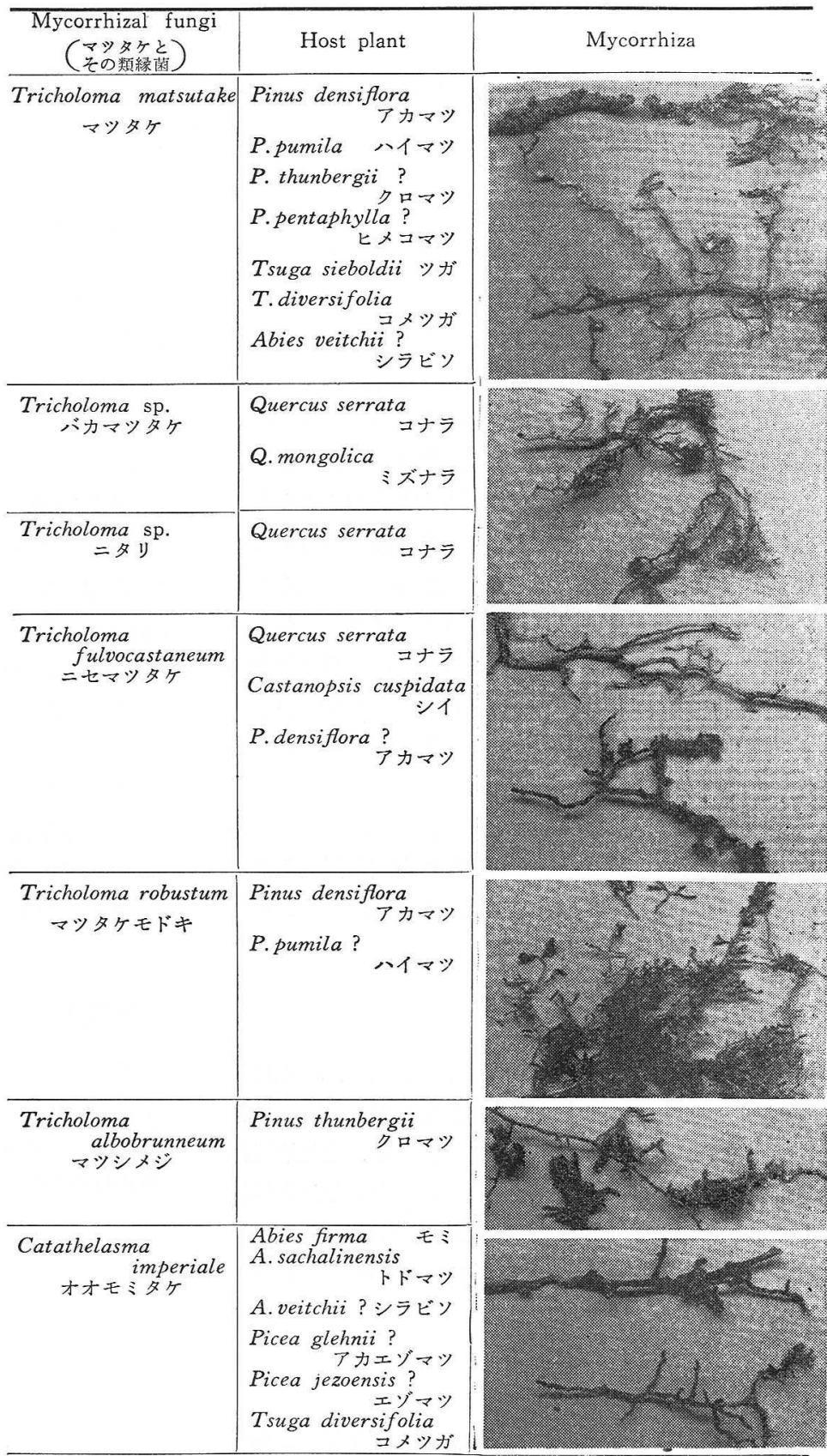

写真は，上からマツタケがアカマツに，バカマツタケがミズナラに，二セマツタケ がシイに，マツタケモドキがアカマツに，マツシメジがクロマッに，才オモミタケが コメツガについた場合の菌根を示す。ニタリはバカマツタケに類似した菌根を作る。
スに，ある段階では重力に，光に，湿度，温度などに支 配されて変わり，運動部位も異なる。これは，おそらく 生長する菌糸の末端に主として感応部位があり，したが 
って胞子形成の段階に応じていると思われる。たとえば， かたまりができるには温度, 伸長するには湿度とガス, かさの展開には光, といった具合に, 各分化段階に応じ て，分化のための条件の支配的要因が変化する．ただし， これはあくまでも他の条件と関連しあったものであって， たとえば光が 10 Iux であればよいといっても, 温度や 湿度が許容範囲になければ有効に働けないのは当然であ る。ある器官なり, 組織なりは常に無からは生じない. いわば歴史的必然である。したがって，かなり広範囲に 考えなければ，きっかけを捉えるのもむずかしくなる。

「きのこは形態形成の問題をといてゆくにはよい材料 だと思いますがね党，どらいらわけかやる人が少なくて， やり始めてもすぐ試験管にとじこめたり, 殺してしまっ たりでねえ, われわれがのびのびと大きくなるのをもっ とじっくり見て考えてくださいよ. 私を扱拈らってのは 無理かもしれないから，まあもっと節操のない奴から手 をつけてごらんなさいよ」とマッタケが言ら、「らょっ と言い過ぎかも知れませんがね, きのこの運動や分化の 問題は高等植物の花芽形成や花の習性とよく似ています よ. 同じ生殖器官ですからね」と, ちょっととっくりか えった.

きのこの形態形成を知るためには，まず，きのこの分 化の段階とその段階を支配する条件の主因を捉えること が先決である、マッタケの人工栽培が困難なのも, その へんに原因があるのかもしれない.

\section{9. 香}

かさが開くとマツタケは特殊な香気を出す、これは cinnamic acid の methylester とされているが, まれ に培養菌系にもこの香りの出ることがある. また培養菌 糸も独特の香りを持っている. それらの生産される経路 は今のところ不明であるが，香気物質は㧤とらく胞子形 成と同時に生産されるもので, 胞子だけからもその香り は強く発生する。

\section{0. 胞子}

胞子の発芽は困難で, 胞子の単個培養も今のところで きないが, soil extractを使らとよく発芽し, 栄養源の ない状態に沶いても $1 \sim 1.5 \mathrm{~cm}$ は伸びる. 胞子にかな りの養分を貯え, 若い根に出会らまで伸びつづること もできよう。しかし, 野外で着生し, 菌根を形成する状 態を見つけることはでさない，実験室的に根につけるこ とは可能である (Sugimura, 未発表).

\section{1.むすび}

「私の親類縁者も私と似たような生活をしていすして ね，菌根を作っているんだが(表 1)，それをくわしく話 して比較してもらわなければわからないし，子実体がで きるときには栄着生長がとまるとか, 他の連中ではえさ が悪くなったり, 環境が栄養生長をするのに琹くなると できるとか，といら子実体形成の大事な問題を拔かして ますよ」と言ら．ここに述べた以上に多くのことをマッ タケは話してくれたが，書いている㗇もない。より具体 的な事実を揭げ，文献を引用して述べる必要があるが， ここでは大筋を述べるにとどめた．

「まったくまとまりのない話で，これではまだ城を明 け渡すことは無理ですね。私は一生䀣命わからせようと 思って話しているんだが，どうも人間は常識にとらわれ 過ぎて，私の言うことを䛊解するし，簡単にわかったも のと自惚れるし，大体あなた方人間も含めて生物っての は独立では生さてゆけないものだし, 柃といらものをも っているし，いっも動いているのだといらことを知って， しっかりつかまえないとわかりっこないですね」と叱ら れた。

当初, われわれが予想した以上に, マッタケは雄弁に 生物の世界を物語ってくれる。その言葉をどのよらに表 現して人間の言葉にかえればよいのか，それがわれわれ に与えられた課題である.

$$
\text { （おがわ・まこと） }
$$

\section{引用文献}

浜田稔ら編：マツタケ一研究と増産一, 1964. 小川真, 浜田稔：日菌報, 6, 67 (1965). 小川真, 浜田稔 : 日本菌学会大会にて講演 (1966). H. Ohara, M. Hamada: Nature, Lond. (in press). H. Ohara: Proc. Jap. Acad., 42, 503 (1966). 